\title{
Malaria on the Guiana Shield: a review of the situation in French Guiana
}

\author{
Lise Musset ${ }^{1}{ }^{+}$, Stéphane Pelleau', Romain Girod ${ }^{2}$, Vanessa Ardillon ${ }^{3}$, Luisiane Carvalho ${ }^{3}$, \\ Isabelle Dusfour ${ }^{2}$, Margarete SM Gomes ${ }^{4}$, Félix Djossou ${ }^{5}$, Eric Legrand ${ }^{1}$
}

\begin{abstract}
${ }^{1}$ Laboratoire de Parasitologie, Centre National de Référence du Paludisme - Région Antilles-Guyane, WHO Collaborating Center for Surveillance of Antimalarial Drug Resistance 2Unité d'Entomologie Médicale, Institut Pasteur de la Guyane, Cayenne, French Guiana ${ }^{3}$ Cellule de I'Institut de Veille Sanitaire en Région Antilles-Guyane, Cayenne, French Guiana ${ }^{4}$ Laboratório Central de Saúde Pública do Amapá, Macapá, AP, Brasil ${ }^{5}$ Unité des Maladies Infectieuses et Tropicales, Centre Hospitalier Andrée Rosemon, Cayenne, French Guiana
\end{abstract}

In a climate of growing concern that Plasmodium falciparum may be developing a drug resistance to artemisinin derivatives in the Guiana Shield, this review details our current knowledge of malaria and control strategy in one part of the Shield, French Guiana. Local epidemiology, test-treat-track strategy, the state of parasite drug resistance and vector control measures are summarised. Current issues in terms of mobile populations and legislative limitations are also discussed.

Key words: malaria - French Guiana - drug resistance - epidemiology - vector control - control strategy

Geography of French Guiana - French Guiana is a French overseas territory located in the northeast of South America, on the Atlantic coast. It is located on one of the oldest and richest deposits of minerals in the world, a Precambrian geological formation, namely the Guiana Shield. This shield underlies French Guiana, Suriname and Guyana and some parts of Venezuela, Colombia and Brazil. Although its $83,534 \mathrm{~km}^{2}$ surface area appears small on the South American scale, French Guiana is the equivalent of $1 / 5$ of the French mainland. It consists of two main geographical regions: the coastal strip, where $90 \%$ of the population live and the inland region covered by dense Amazonian rainforest (Fig. 1). The climate is equatorial with a short rainy season from mid-December to February, a short dry season in March, a long rainy season from April to mid-July and a long dry season from mid-July to mid-December. The average temperature is $29^{\circ} \mathrm{C} \pm 1.2^{\circ} \mathrm{C}$. The population has doubled over the last 20 years and reached 240,000 inhabitants in 2012 (Insee 2012). This high population growth could be explained by a high birth rate (3.5 total fertility rate in 2011) and by significant immigration from surrounding Amazonian and Caribbean countries, mainly to obtain better living conditions $(30 \%$ of the population were foreign in 2010). Consequently, the French Guianan population is a mosaic of origins and nationalities. The four earliest populations are the Amerindians (Indigenous people), the Maroons (descendants

\footnotetext{
doi: 10.1590/0074-0276140031

Financial support: European Commission (REGPOT-CT-2011-285837-STRONGER)

+Corresponding author: lisemusset@gmail.com

Received 24 January 2014

Accepted 9 June 2014
}

of slaves who escaped slavery before its abolition), the French and the Creoles (people of mixed origin). Other communities (listed from the most to least numerous) include the Surinamese, the Haitians, the Brazilians, the Hmong and the Chinese. French Guiana is part of the European Union and its economic activity is mainly based on the tertiary, spatial and building sectors. The mineral wealth of its subsoil (Fig. 1) has resulted in legal, but also illegal gold mining activities. Although this activity has always been part of the French Guianan economy, this sector is currently increasing in proportion to the value of gold (Hammond et al. 2007). Two thirds of the exported gold is illegal and around 7,000 people ( $90 \%$ of whom are illegal migrants) are involved in this activity (WWF 2010). The situation is similar throughout the Guiana Shield, with more than 20,000 Brazilian and Maroon people working in the gold mining sector in Suriname (de Theije \& Heemskerk 2009) and around the same number of people in Guyana (Colchester et al. 2002). Gold mining is responsible for a great amount of illegal human migration in the rainforest, mostly involving Brazilian citizens (de Theije \& Heemskerk 2009).

Epidemiology of malaria - Historical data - Along with Mayotte Island (Mozambic Channel), French Guiana is one of the two French overseas territories which are still malaria endemic (Tarantola et al. 2011). Malaria transmission was high throughout the territory at the beginning of the XX century and eradication campaigns began in the 50s. The association of indoor residual spraying of DDT and mass distribution of amodiaquin salts over a few years led to a spectacular regression of the disease in the territory (Floch 1954). In the 70s, mean general incidence had dropped to 6.4 cases per 1,000 inhabitants (Juminer et al. 1981).

When the eradication campaign ceased, the figure promptly increased to 19.3 cases per 1,000 inhabitants in the 80s (Juminer et al. 1981, Lepelletier et al. 1989, Mouchet et al. 1989). During this period, transmission 


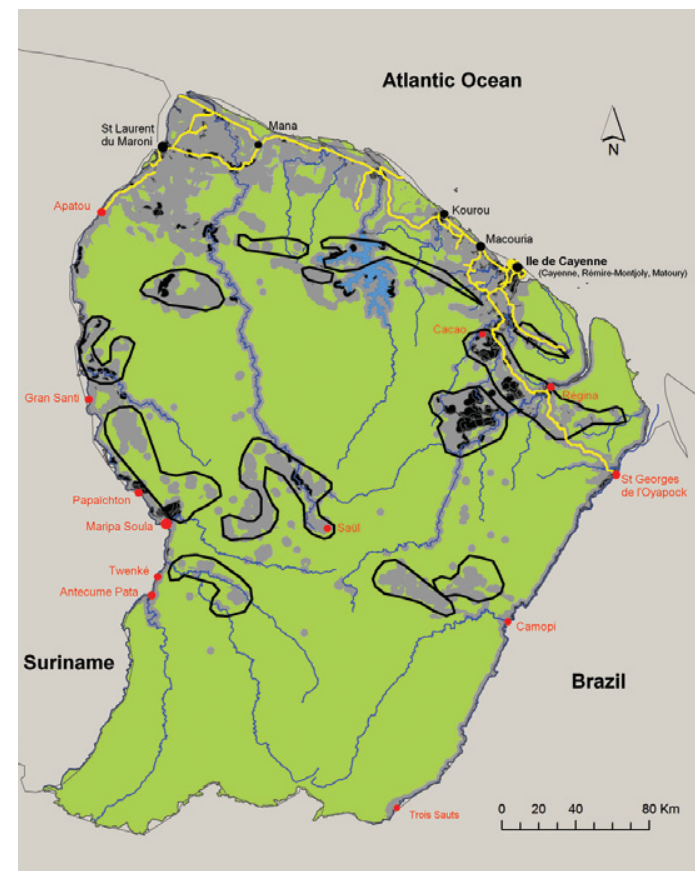

Fig. 1: geography of French Guiana. Only the main rivers are represented. The rainforest is in green. The areas facing anthropic impact are represented in gray (medium) and black (high) (de Thoisy at al. 2010). Gold wealth subsoil is circled in black. The entire road network is represented in yellow. All towns and villages located in a malaria endemic area and reporting malaria cases are represented in red. In these latter, cares are provided only by a health centre.

occurred along the Maroni and Oyapock rivers, representing $80 \%$ and $20 \%$ of the cases, respectively. Along the Maroni, the incidence of 360 cases per 1,000 inhabitants was almost exclusively linked to Plasmodium falciparum (Strobel et al. 1985, Esterre et al. 1990). Very few Plasmodium malariae cases were observed each year in this part of the region. This species was very similar to Plasmodium brasilianum, transmitted by monkeys in the wild. In fact, these two species may be one and the same in this region (Fandeur et al. 2000, Volney et al. 2002). Plasmodium vivax has always been rare along the Maroni, where the population is predominantly composed of Maroon people of African descent with a natural resistance to this parasite species; cases only occurred in some Amerindian communities in the upper part of the river. On the Oyapock side, the incidence in the 80 s was about 485 cases per 1,000, of which $30 \%$ of cases were due to $P$. vivax (Juminer et al. 1981). Little transmission was observed in the coastal area (incidence 9.3 cases per 1,000 inhabitants).

In the $90 \mathrm{~s}$, this general picture persisted with a general incidence of 26 cases per 1,000 inhabitants and around 3,500 symptomatic cases each year, making French Guiana one of the worst affected American territories (Carme \& Venturin 1999, InVS 2006).

From the early $2000 \mathrm{~s}$, a resurgence of the disease $(+100 \%$ and $+390 \%$ regarding $P$. falciparum and $P$. vivax, respectively) was observed in the inner regions and especially in the eastern part of the territory (Carme 2005a, b, Carme et al. 2005). On the Oyapock River, proximity to the river and to the forest was associated with an higher risk of malaria in children (Hustache et al. 2007, Stefani et al. 2011).

Current situation - For the last 10 years, the epidemiology of malaria in French Guiana has changed along with regional land use and the control strategies applied on the Guiana Shield (Breeveld et al. 2012). An increase in the number of $P$. vivax cases was observed, contrasting with the decrease in the number of cases due to $P$. falciparum (Carme et al. 2009). P. vivax cases had outnumbered $P$. falciparum cases in 2005 and this species was responsible for $70 \%$ of all malaria cases in 2012 (Fig. 2). The prevalence of the disease has decreased since 2009, with less than 1,000 cases diagnosed in 2012 (Ardillon et al. 2012, 2013). This decrease in the number of cases occurred two years after the implementation of artemisinin derivative-based therapeutics (Carme \& Meeting Group 2002) and the mass distribution of long-lasting impregnated bed nets (Mansotte et al. 2010a).

More specifically, transmission is very low on the Maroni river with an incidence of 3.1 cases per 1,000 inhabitants in 2012 that is essentially related to gold mining activities in Suriname or in French Guiana (Ardillon et al. 2013) (Fig. 3). This decrease in transmission on the Maroni is probably linked to the strong elimination strategy conducted on the Surinamese part of the river since 2008, namely the Looking for Gold, Finding Malaria program, granted by the Global Fund (Breeveld et al. 2012, Hiwat et al. 2012). However, a resurgence of the disease was observed in the inland region (Saül, Cacao, Régina) and eastern French Guiana (St Georges de l'Oyapock and Camopi), where the general incidence reached 55.2 cases per 1,000 inhabitants in 2013 (Carme 2005b, Berger et al. 2012, Ardillon et al. 2013, Basurko et al. 2013, Nacher et al. 2013b). Indeed, several arguments establish a link between this high disease incidence and human migration within the rainforest for gold mining activities: (i) the people presenting malaria infection are primarily a working age population (incidence of 5 symptomatic malaria cases per thousand inhabitants for people aged between 18-34 years old comparing to an incidence of 2.4 and 2.7 for those aged between six-17 years old and 35 and 59 years old, re-

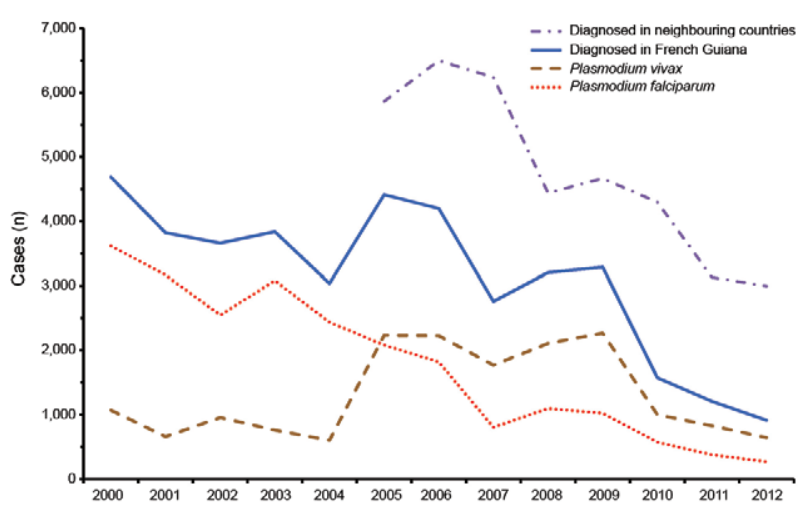

Fig. 2: number of malaria cases from French Guiana since 2000. 
spectively), (ii) transmission is observed to decrease in the area during military operations which limit human migration for gold mining (Berger et al. 2012), (iii) the military personnel are highly infected after missions in the deep forest to combat illegal gold mining (Verret et al. 2006, Queyriaux et al. 2011), (iv) a large percentage of infected people (30\%) in the state of Amapá, Brazil share the occupational activity of gold mining, (v) a high number of the cases diagnosed in Suriname and Brazil (3,000 cases in 2012) are reputed to have originated from French Guiana and (vi) many patients presenting malaria symptoms are of Brazilian origin (Carme 2005b).

Nowadays, autochthonous transmission is sporadic on the coast, with few spots in the municipalities of Matoury and Macouria (Fig. 3). As soon as a malaria case is identified on the coast, epidemiological data are collected by the vector control services of the General Council of French Guiana in order to identify where the contamination occurred (Chocho et al. 2011).

Entomological knowledge - The primary vector of malaria in French Guiana is Anopheles darlingi, the most common and efficient malaria vector in the Americas. Historically, this species has been known to be responsible for spreading the disease throughout the territory because of its wide distribution, its anthropophilic behaviour, its natural infectability, its high density during the annual rises in malaria and its sensitivity to $P$. falciparum (Floch \& Abonnenc 1951, Floch 1955, Mouchet et al. 1989, Claustre et al. 2001). More recent studies have clearly shown its implication in malaria transmission within endemic villages - especially along the Maroni River, where the species has been shown to be naturally infected by $P$. falciparum, $P$. vivax and $P$. malariae (Girod et al. 2008, Fouque et al. 2010, Hiwat et al. 2010) and along the Oyapock River, where it has been observed to be infected with $P$. vivax only (Dusfour et al. 2012a). Nevertheless, the occasional or local involvement of other species which are known to be primary or secondary vectors across the Neotropics cannot be ruled out in some areas (Floch \& Abonnenc 1951, Pajot et al. 1978, Mouchet et al. 1989, Carme et al. 2009, Girod et al. 2011, Stefani et al. 2011). Among these species, Anopheles intermedius, Anopheles oswaldoi and Anopheles nuneztovari have recently been found to be naturally infected with $P$. falciparum in different locations (Dusfour et al. 2012a). Moreover, the presence of Anopheles marajoara, considered as a major malaria vector in Amazonia, was confirmed in 2011 in the environmental context of an illegal gold mine in the deep forest (Dusfour et al. 2012b).

Control strategy and current issues - Test, treat... The test and treat strategy relies on a network of public and private professionals that enables patients to be diagnosed and treated close to their homes (Fig. 1). The private medical sector is composed of one hospital in Kourou and a number of general practitioners $(\mathrm{n}=371)$, medical laboratories $(n=7)$ and pharmacies $(n=47)$. Drug distribution is well regulated and follows French Agency for Drug Safety directives. The public health sector is composed of hospitals in the two main towns of French Guiana - one in Saint Laurent du Maroni and

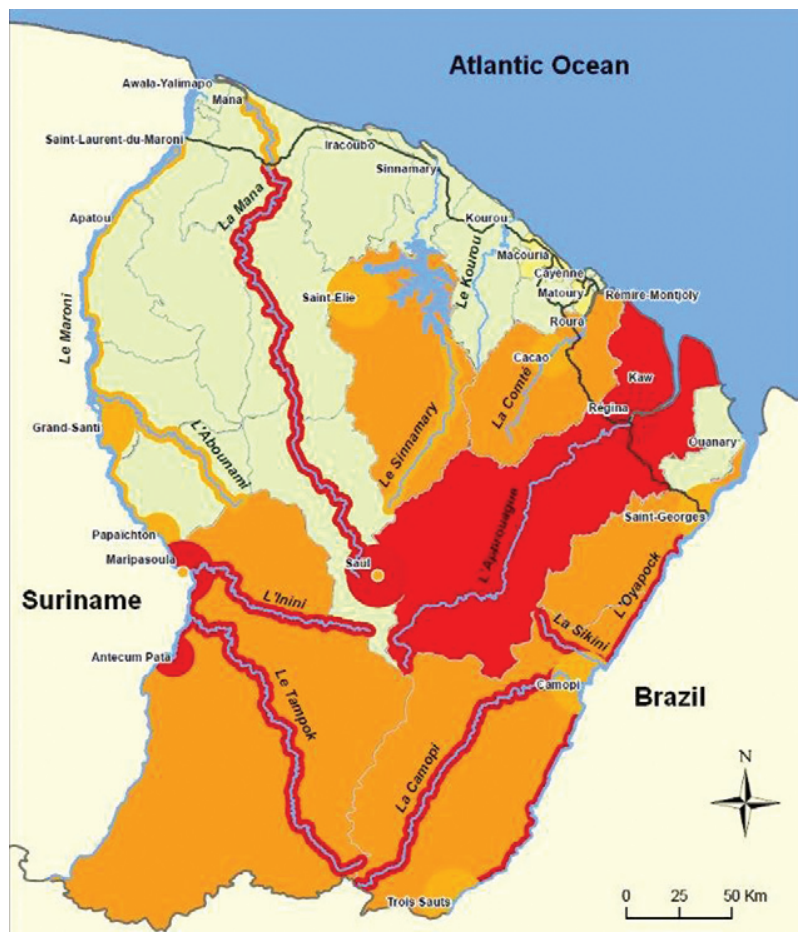

Fig. 3: risk of malaria in French Guiana between September 2012 and March 2013. This map represents the risk of malaria contamination at the municipality scale. This risk is calculated from the number of registered malaria cases, the presence of Anopheles vector and gold mining activities in the municipality. Municipalities with very low risk of malaria are represented in yellow. Orange represents low risk and red, the highest risk. Between April and August, the three municipalities on the east, namely St Georges de l'Oyapock, Camopi and Trois Sauts, are generally at low risk because of the seasonality of transmission.

the other in Cayenne. Cayenne Hospital also administers 18 rural health centres, which are spread over the entire territory. In the smallest and most remote of these healthcare facilities, also named health posts, the health provider team consists of just one nurse. National medical insurance, associated with complementary health insurance, covers medical expenses at the individual level for diagnosis and treatment in the public health sector and illegal migrants have free access to care when it concerns children under 16, pregnancy, transmissible diseases or life-threatening diseases such as malaria (circular of 16 March 2005).

Until 2000, malaria diagnosis using microscopy was widespread in French Guiana. However, owing to the difficulty of maintaining highly skilled microscopists in the health centres located in remote rural areas and the frequent need for the maintenance of equipment, the Rapid Diagnosis Test (RDT) replaced this gold standard method in some health centres from 2000 onwards, then became the norm in all health centres after 2007 (Carme 2005a). The Optimal-IT ${ }^{\circledR}$ kit (pLDH-pan + pLDH-pf) has been used for more than 10 years, but owing to its relatively low sensitivity for the detection of $P$. falciparum, it was replaced in 2011 by the SD Malaria Ag P.f/Pan ${ }^{\circledR}$ kit (pLDH-pan + PfHRP2), which is more sensitive (as 
TABLE

Therapeutic recommendations for malaria in 2013 in French Guiana

\begin{tabular}{|c|c|c|c|c|}
\hline & \multicolumn{3}{|c|}{ Plasmodium falciparum } & \multirow[b]{2}{*}{ Plasmodium vivax } \\
\hline & Prophylaxis & Uncomplicated cases & Severe cases & \\
\hline 1st line & Atovaquone-proguanil & Artemether-lumefantrine & $\begin{array}{l}\text { Artesunate IV followed by } \\
\text { artemether-lumefantrine }\end{array}$ & $\begin{array}{c}\text { Chloroquine } \\
+/-\end{array}$ \\
\hline 2nd line & Doxycycline & Atovaquone-proguanil & Quinine-doxycycline IV & primaquine \\
\hline
\end{tabular}

there are no parasites lacking the pfhrp2 gene in French Guiana), has greater stability across a wide temperature range and is less expensive (Trouvay et al. 2013).

Less than 10 severe $P$. falciparum cases are registered each year and are responsible for few or no malaria deaths annually thanks to the efficient health care system implemented in French Guiana (2 cases in 2011, none in 2012). Patients presenting severe $P$. vivax cases are also rare and these cases are generally associated with significant digestive disorders. Plasmodium vivax infections present a pure Chesson (tropical) pattern with a peak of relapses occurring within three months of the primary infection and generally 28-30 days later (Ehrman et al. 1945, Hanf et al. 2009).

The therapeutic policy for the treatment of uncomplicated $P$. falciparum cases recommends the use of artemether/lumefantrine (Riamet $^{\circledR}$ in France, Coartem ${ }^{\circledR}$ elsewhere in South America), preceded by intravenous artesunate $\left(\right.$ Malacef $\left.^{\circledR}\right)$ for severe cases (Table) (Carme \& Meeting Group 2002). Although the use of artemether/ lumefantrine was recommended in 2002 , lengthy administrative formalities delayed its use in medical practices until 2007. Nowadays, it is only available in the public health sector. The combination dihydro-artemisinin/piperaquine (Eurartesim ${ }^{\circledR}$ ) has been available since 2013, but is not covered by health insurance and has therefore not been used on a wide scale. Primaquine (PQ) single dose cannot be used to eliminate $P$. falciparum gametocytes in French Guiana, as this drug has not been officially approved in the European Union for this specific purpose. Chloroquine (CQ) (Nivaquine ${ }^{\circledR}$ ) is recommended for the treatment of $P$. vivax cases, followed by PQ $(15 \mathrm{mg} /$ day for 14 days until 2008 and, due to administrative constraints, $30 \mathrm{mg}$ /day for 14 days since 2009) after screening for G6PD deficiency (HCSP 2008). In the absence of official approval, PQ could be prescribed against hypnozoites under a special administrative status named "temporary authorisation for use", which requires specific formalities to be carried out for each individual treated. This situation, associated with the difficulty of screening G6PD deficiency in remote areas, greatly delays the administration of PQ following diagnosis of a primary infection (Nacher et al. 2013b). The following solutions have been suggested to reduce this time: (i) the systematic screening of all babies for G6PD deficiencies at birth in the hospital and (ii) the evaluation of rapid G6PD tests to allow them to be used directly in the field or the implementation of widescale G6PD screening in the highest endemic areas. As previously underlined, it is perplexing that this long-established drug still does not have official approval in France, 61 years after Food and Drug Administration approval (Nacher et al. 2013b). Access to treatment is a core element of malaria control and elimination programs, as recommended by World Health Organization (WHO 2013). However, the numerous administrative constraints in French Guiana limit antimalarial drug usage. The fact that high authorities are located in Paris or Bruxelles is probably detrimental and does not help to solve the problem as the context of this overseas territory, endemic for malaria, is often poorly known and is not particularly seen as a priority.

Travellers to endemic areas should protect themselves from $P$. falciparum by taking a suitable prophylaxis, namely atovaquone/proguanil (Malarone ${ }^{\circledR}$ ) or doxycycline $\left(\right.$ Doxypalu $^{\circledR}$ ) (Carme \& Meeting Group 2002). The cost of prophylaxis by three medications (atovaquone/proguanil adult, mefloquine, $\mathrm{CQ} /$ proguanil) has been covered by national medical insurance cover since 2009 for local travellers living on the coast who travel to an endemic area for less than three months, in order to limit transmission on the coast. Although this procedure is good, it does not fully meet the regional recommendations and would be more efficient if it included doxycycline.

...Track - Case tracking - Nowadays, the epidemiological surveillance of malaria in French Guiana is based on an extensive census of all malaria cases diagnosed in the territory (in medical laboratories, hospitals and health centres). This monitoring system, organised by the epidemiologists of the National Institute for Public Health Surveillance's regional unit, is based on a weekly compendium of cases in order to trigger an alert in case of outbreaks or local transmission on the coastal area. This system only considers infected people who have been passively diagnosed within the framework of private and public health sectors. Regular data exchanges are carried out with bordering countries. The regional epidemiology unit of French Guiana reports any cases diagnosed along the Maroni and Oyapock rivers to Surinamese and Brazilian counterparts every week, including the putative contamination places. Data is received on a weekly basis from Suriname and once a month from Brazil. These exchanges show a large number of cases that most probably originated in French Guiana, but were diagnosed in Suriname or Brazil (Fig. 2). This number increases when illegal migrants do not have easy access to the healthcare system; this is particularly true in small villages where French military presence pushes them to stay in the forest and manage with locally available means. 
Drug resistance tracking - It is of utmost importance for public health to detect any signs of decreased drug efficacy or greater in vitro resistance (WHO 2011, 2013). In French Guiana, this surveillance has been performed continuously since 1988 by the National Reference Centre for Malaria (NRC), hosted by the parasitology laboratory of the Pasteur Institute of French Guiana (Esterre et al. 2009). The NRC for malaria (i) evaluates the in vitro chemosusceptibility of parasites using the isotopic semimicro test method (Le Bras \& Deloron 1983) in order to quantify the concentration of drugs inhibiting $50 \%$ of the parasite growth in vitro [inhibitory concentration of $50 \%$ $\left.\left(\mathrm{IC}_{50}\right)\right]$ and (ii) performs genotyping methods to monitor the prevalence of mutations in genes associated with drug resistance. Since 2009, it has worked in collaboration with the infectious diseases unit of Cayenne Hospital to evaluate at the clinical level the drug efficacy of artemether/ lumefantrine for $P$. falciparum and CQ for $P$. vivax, according to WHO recommendations (WHO 2009a).

To fulfill its mission, the NRC collects blood samples from all the diagnosis centres throughout the territory. The number of collected samples $(48 \%$ and $39 \%$ of the registered malaria cases in French Guiana in 2012 for $P$. falciparum and $P$. vivax, respectively, including samples from gold miners) is considered high enough to be a good proxy of the general situation in French Guiana and even the Guiana Shield.

Like everywhere else in the world, the susceptibility of $P$. falciparum to drugs in this area evolved following changes in drug use. After the generalisation of CQ resistance during the 90s, this drug was officially replaced in 1995 (Dedet et al. 1988, Reynes et al. 1997). The combination of quinine and doxycycline became the first line and mefloquine or halofantrine the second line for the treatment of uncomplicated cases although in practice, the last two drugs were predominantly prescribed by practitioners. This change led to a first drop in $\mathrm{CQ} \mathrm{IC}_{50}$ in 2000 (Legrand et al. 2008). Since 2008, around 30\% of the isolates have remained resistant to CQ. One reason for this incomplete return to full susceptibility might be an indirect pressure exerted on P. falciparum by CQ due to its use in treating $P$. vivax infections. Susceptibilities to mefloquine and halofantrine globally decreased through their widespread use in French Guiana from 1995-2005 (up to $60 \%$ and $30 \%$ of isolates with decreased susceptibility for each drug, respectively). This trend was interrupted and reversed around 2008, when the use of ACT was fully implemented. Globally, mean in vitro susceptibilities for artemether and lumefantrine remained high and stable over time (Legrand et al. 2008).

The prevalence of molecular markers associated with $\mathrm{CQ}$ and 4-amino-quinoleine resistance, $p f c r t$ and $\mathrm{pfm}$ $d r l$, have been evaluated since 2000. The mutant $p f m d r l$, haplotype NFCDY, and the mutant pfcrt of the 7G8-type $(\underline{S V M T})$ actually reached fixation $(>94 \%)$ in the early 2000's, thus preventing any association with phenotypes (Legrand et al. 2012). Indeed, this situation markedly differs from events in other endemic areas on other continents, where parasites with the wild-type $p f c r t$ haplotype CVMNK re-emerged after CQ withdrawal (Kublin et al. 2003, Wang et al. 2005, Mohammed et al. 2013).
The fact that a large proportion of $P$. falciparum parasites became susceptible to CQ again while keeping a mutant genotype seems to indicate that all wild-type $p f c r t$ were eliminated from the effective population after decades of CQ use and that novel polymorphisms restoring fitness and also susceptibility have been acquired on a resistant genetic background. Only the copy number of the pfmdrl gene could be correlated with mefloquine and halofantrine chemosusceptibilities $(r=0.64$ and 0.47 , respectively, $\mathrm{p}<0.001)$. The correlation with quinine, artemether and lumefantrine was more moderate, although significant $(\mathrm{r}<0.4, \mathrm{p}<0.001)$, and suggested that this gene could only partially explain these phenotypes.

In the 2000's, seven isolates were found to have a decreased in vitro susceptibility to artemether, six of them being associated with a S769N mutation in the pfatpase6 gene (Jambou et al. 2005). We could not confirm these observations and, finally, the association between this mutation and artemether resistance has not been confirmed in either Southeast Asia (Dondorp et al. 2010) or Suriname (Adhin et al. 2012). The prevalence of mutations in the resistant marker recently identified in Southeast Asia (Ariey et al. 2014) should be evaluated on previously observed isolates that exhibit decreased susceptibility in order to test its validity in French Guiana.

The atovaquone/proguanil combination is occasionally used to treat uncomplicated cases on the coast. Less than two therapeutic failures due to resistance are identified each year, systematically associated with parasites harbouring a mutation on codon 268 of the mitochondrial pfcytb gene (Legrand et al. 2007). This situation is comparable with that observed in travellers on the France mainland (Musset et al. 2006, 2007).

Regarding $P$. vivax, this species has been neglected for several years due to the epidemiology in French Guiana and its relative absence in severe malaria. Preliminary data of the drug efficacy study show a small proportion of $P$. vivax resistant to CQ (unpublished data). The main limitation when evaluating resistance of $P$. vivax is the difficulty to breed this species in culture, even over a short period of time. Studies have therefore focused on the P. falciparum ortholog genes previously validated as molecular markers of resistance in $P$. falciparum. The mutant genotype of the $p v d h f r$ and $p v d h p s$ genes, implicated in $P$. falciparum resistance to sulfadoxine/pyrimethamine, exhibited a fixation in French Guiana from before 2000, when there was no known direct drug pressure using this combination (Barnadas et al. 2009). The pvmdrl genotype has also been analysed in very few isolates $(n=5)$ (Brega et al. 2005, Picot et al. 2005). The mutation on codon 976 was not observed.

Nowadays, $P$. falciparum parasites are almost fully susceptible to drugs recommended in therapeutics and cases of confirmed clinical resistance are exceptions (Demar \& Carme 2004, Bertaux et al. 2011). No indisputable molecular markers have been yet validated for CQ, quinine, artemether or lumefantrine. This highlights the necessity to identify and validate new molecular markers for this part of the world, where parasite drug resistance can appear de novo and in situ. In addition, the diversity, structure and recombination dynamics of parasite populations must be taken into account when looking for 
molecular markers and validating them, as these factors are poorly known for both species in this region (Ariey et al. 1999, 2001, Veron et al. 2009).

In addition to molecular markers, it will also be necessary to implement an in vitro test for $P$. vivax and new in vitro methods for $P$. falciparum that can detect any change in artemisinin susceptibility better than the regular semi micro tests (Witkowski et al. 2013), then attempt to correlate these results with the recent clinical observation that at least $5 \%(n=3 / 53)$ of artemether/lumefantrine treated patients are still parasitaemic at day 3 (unpublished data).

Vector control - Vector control in French Guiana is carried out both by local (Mosquito Control and Health Activities of the General Council) and national (Regional Health Agency) health authorities. It is based on indoor spraying operations with residual pyrethroids (Cislin ${ }^{\circledR} 25 . \mathrm{VO}$ at the dose of $25 \mathrm{mg} / \mathrm{m}^{2}$ of deltamethrin) and, more recently, on the distribution of bed nets impregnated with pyrethroids (Permanet ${ }^{\circledR} 2.0$ impregnated with $55 \mathrm{mg} / \mathrm{m}^{2}$ of deltamethrin) (InVS 2006, Mansotte et al. 2010b). They are complemented by larviciding operations carried out with different formulations of Bacillus thuringiensis israelensis serotype $\mathrm{H} 14$ (VectoBac ${ }^{\circledR} \mathrm{G}$ at the dose of $2.5-10 \mathrm{~kg} / \mathrm{ha}$ depending on the configuration of the breeding places).

In endemic areas, nets are systematically distributed and spraying operations are implemented two or three times a year according to a pre-established program. Thus, current vector control strategy is not guided by entomological surveillance. At best, larval surveys help identify positive Anopheles breeding places. In the coastal region, when a malaria case is reported, an entomological investigation is carried out, including a search for larvae in breeding places close to the patient's home. In this case, vector control operations are implemented accordingly to the results obtained.

An improvement of the vector control program in French Guiana can no doubt be achieved through the necessary monitoring of Anopheles populations to acquire data on insecticide susceptibility, population dynamics and malaria transmission levels. This could help optimise the use of insecticides and enable local authorities to anticipate epidemic risk and therefore set priorities for vector control interventions according to the entomological situation. Two further points require discussion. Firstly, the relevance of implementing indoor residual spraying and distributing long-lasting impregnated nets should be discussed, as both measures use the same active molecule without any previous evaluation of the benefit/risk regarding human and environmental toxicity and the emergence of insecticide resistance (WHO 2009b, 2010). Secondly, decision-makers should consider the interest and feasibility of implementing wide-scale educational campaigns to encourage the use of skin repellents in a context where Anopheles vectors also bite at times and places when/where residents are not protected by their nets.

Nevertheless, it is not easy to implement the monitoring of Anopheles populations in the Amazonian Region because the conventional methods for the collection of adult Anopheles (human landing catches) and the measurement of malaria transmission indices (identifying
Anopheles species, determining the longevity of populations by dissecting females, assessing of infection rates etc.) are difficult to deploy on a large scale in the field. However, these issues could be dealt by developing new and efficient methods that can easily be implemented in the field and in the lab (i.e., the use of effective attractants and trapping techniques and molecular tools to identify Anopheles species and determine the age of females, their infection rates etc.) (James et al. 2014). The limited knowledge of the biology and the ecology of suspected vector species (exophily/endophily, exophagy/endophagy, circadian biting rhythm etc.) is also a drawback, especially in a context where the behaviour of a species could change according to meteorological and environmental factors (Tadei et al. 1998, Girod et al. 2011, Hiwat \& Bretas 2011, Dusfour et al. 2013). Finally, the difficulties of rearing An. darlingi and other potential vector species from South America in an insectary also limit the acquisition of data regarding their susceptibility to insecticides.

The difficult issue of gold mining activities - As described throughout this review, the gold mining activity is the main factor responsible for high levels of illegal human migration throughout the entire Guiana Shield and has an impact on the malaria situation in this region. However, national policies towards gold mining differ according to the country concerned. In Suriname and Guyana, there are several legal mining contracts associated with public incomes and taxes. In Suriname, the authorities take the transmission of malaria within these populations into account and have adapted their malaria elimination program to diagnose and treat people on site, in the mines or in a special laboratory located in Paramaribo, specifically adapted to the workers' needs. In French Guiana, legal contracts are rare and gold mining activities are frowned upon. In fact, the French government who are in line with public opinion wish to curb mining activities, notably because of their disastrous environmental impact on biodiversity hotspots. The French government has been tracking illegal gold miners since 2002. After a first deployment of police operations, this struggle has intensified and now relies on three approaches. The first one is an observatory of mining activities. Created in 2009, this organisation aims to follow the mining activities and their impact on the environment based on the information collected by different structures, namely the national offices for the forest (Office National des Forets) and the Amazonian natural reserve of French Guiana (Parc Amazonien de Guyane), the army and other partners. Secondly, this struggle now involves the French Army through the Harpie military operation. This operation aims to paralyse the illegal gold mining sites throughout the territory by systematically destroying their equipment and policing the movement of suppliers on the rivers. Lastly, a transborder collaboration with Brazil has led to the ratification of an agreement by the House of Representatives (Decree 1055/2013) which aims to strengthen the fight against illegal gold mining in national parks and border areas through the confiscation and destruction of property used in illegal gold mining, within a range of $150 \mathrm{~km}$ on either side of the border between the state of Amapá and French Guiana. To be effective, this agreement still needs the approval of the Brazilian Senate. 
In this context, it is difficult for France to implement a regional malaria control program that takes these putative hotspots of transmission directly into account. Nevertheless, reaching these populations to prevent, diagnose and treat malaria in the forest is a major challenge that has already been underlined and discussed with pragmatism (Nacher et al. 2013a). Moreover, this hidden face of malaria transmission is characterised by erratic self-medication using illegally imported antimalarial drugs of unknown quality by mining workers (Evans et al. 2012). In this situation, all the conditions for the emergence of drug resistance are met and they have already been described for artemether/lumefantrine in Suriname and Guyana (Vreden et al. 2013). Nowadays, the artemisinin derivatives are the only effective combination to treat malaria and it is essential to preserve their efficacy as long as possible if malaria elimination is to be achieved.

Concluding remarks - French Guiana is a piece of the European Union in Amazonia and is the only noninsular overseas territory of France facing malaria. Its malaria control program has several strengths which are both perennial and independent of external funding: (i) the general diagnosis and free treatment for the inhabitants with diagnostic tools and drugs of quality, (ii) the epidemiological surveillance of malaria cases, (iii) the constant monitoring of drug resistance for over 25 years and (iv) the vector control and prevention, including the distribution of long-lasting impregnated bed nets.

In a current context where local health authorities are committed to move torwards a malaria elimination in French Guiana, this small part of Europe should build a strong and integrated local malaria elimination program that is led by a program manager with sufficient resources to implement his duty (Fischer 2012) and takes all the components of the issue into consideration. This is dependent upon a clear interest of the central French authorities, whose involvement is crucial in order to overcome legal difficulties and allocate additional resources. The governments of the Guiana Shield countries also need to set up policies to attain the same goal. International funders are therefore of paramount importance to facilitate the continuation of a transborder cooperation which takes innovative, coherent, integrative and coordinated control measures adapted to the aspects and specificities of each country concerned.

\section{ACKNOWLEDGEMENTS}

To the Health Centre coordination and all partners working on malaria in French Guiana, to B de Thoisy, for helping in figure design and helpful suggestions of the paper, and to $\mathrm{H}$ Bogreau, for critical reading of the paper.

\section{REFERENCES}

Adhin MR, Labadie-Bracho M, Vreden SG 2012. Status of potential PfATP6 molecular markers for artemisinin resistance in Suriname. Malar J 11: 322.

Ardillon V, Carvalho L, Prince C, Djossou F 2013. 2012: epidemiology of malaria in French Guiana. Bull Veille San 4: 6-10.

Ardillon V, Eltges F, Chocho A, Chantilly S, Carvalho L, Flamand C, Carme B 2012. Evolution of malaria epidemiology between 2005 and 2011 in French Guiana. Bull Veille San 1: 5-11.
Ariey F, Chalvet W, Hommel D, Peneau C, Hulin A, Mercereau-Puijalon O, Duchemin JB, Sarthou JL, Reynes JM, Fandeur T 1999. Plasmodium falciparum parasites in French Guiana: limited genetic diversity and high selfing rate. Am J Trop Med Hyg 61: 978-985.

Ariey F, Hommel D, Le Scanf C, Duchemin JB, Peneau C, Hulin A, Sarthou JL, Reynes JM, Fandeur T, Mercereau-Puijalon O 2001. Association of severe malaria with a specific Plasmodium falciparum genotype in French Guiana. J Infect Dis 184: 237-241.

Ariey F, Witkowski B, Amaratunga C, Beghain J, Langlois AC, Khim N, Kim S, Duru V, Bouchier C, Ma L, Lim P, Leang R, Duong S, Sreng S, Suon S, Chuor CM, Bout DM, Menard S, Rogers WO, Genton B, Fandeur T, Miotto O, Ringwald P, Le Bras J, Berry A, Barale JC, Fairhurst RM, Benoit-Vical F, Mercereau-Puijalon O, Menard D 2014. A molecular marker of artemisinin-resistant Plasmodium falciparum malaria. Nature 505: 50-55.

Barnadas C, Musset L, Legrand E, Tichit M, Briolant S, Fusai T, Rogier C, Bouchier C, Picot S, Menard D 2009. High prevalence and fixation of Plasmodium vivax dhfr/dhps mutations related to sulfadoxine/pyrimethamine resistance in French Guiana. Am $J$ Trop Med Hyg 81: 19-22.

Basurko C, Demattei C, Han-Sze R, Grenier C, Joubert M, Nacher M, Carme B 2013. Deforestation, agriculture and farm jobs: a good recipe for Plasmodium vivax in French Guiana. Malar J 12: 90.

Berger F, Flamand C, Musset L, Djossou F, Rosine J, Sanquer MA, Dusfour I, Legrand E, Ardillon V, Rabarison P, Grenier C, Girod $R$ 2012. Investigation of a sudden malaria outbreak in the isolated Amazonian village of Saul, French Guiana, January-April 2009. Am J Trop Med Hyg 86: 591-597.

Bertaux L, Kraemer P, Taudon N, Trignol A, Martelloni M, Saidi R, Parzy D, Pradines B, Simon F 2011. Quinine-resistant malaria in traveler returning from French Guiana, 2010. Emerg Infect Dis 17: 943-945.

Breeveld FJ, Vreden SG, Grobusch MP 2012. History of malaria research and its contribution to the malaria control success in Suriname: a review. Malar J 11: 95.

Brega S, Meslin B, de Monbrison F, Severini C, Gradoni L, Udomsangpetch R, Sutanto I, Peyron F, Picot S 2005. Identification of the Plasmodium vivax mdr-like gene ( $p v m d r l$ ) and analysis of single-nucleotide polymorphisms among isolates from different areas of endemicity. J Infect Dis 191: 272-277.

Carme B 2005a. Epidemiology and diagnosis of malaria in French Guiana. Rev Fr Lab 374: 21-25.

Carme B 2005b. Substantial increase of malaria in inland areas of eastern French Guiana. Trop Med Int Health 10: 154-159.

Carme B, Meeting Group 2002. Consensus on malaria in French Guiana. Available from: invs.sante.fr/publications/bvs/antilles guyane/2011/bvs_ag_2011_01.pdf.

Carme B, Ardillon V, Girod R, Grenier C, Joubert M, Djossou F, Ravachol $\mathrm{F} 2009$. Update on the epidemiology of malaria in French Guiana. Med Trop (Mars) 69: 19-25.

Carme B, Lecat J, Lefebvre P 2005. Malaria in an outbreak zone in Oyapock (French Guiana): incidence of malaria attacks in the American Indian population of Camopi. Med Trop (Mars) 65: 149-154.

Carme B, Venturin C 1999. Malaria in the Americas. Med Trop (Mars) 59: 298-302.

Chocho A, Bellony S, Azor P, Chantilly S 2011. Suspected contamination places of malaria cases diagnosed on the coast of French Guina, 2009. Bull Veille San 1: 6-10.

Claustre J, Venturin C, Nadire M, Fauran P 2001. Malarial vectors in French Guiana: study in an epidemic focus near Cayenne (19891998). Bull Soc Pathol Exot 94: 353-357. 
Colchester M, La Rose J, James K 2002. Mining and Amerindians in Guyana. The North-South Institute. Available from: idl-bnc.idrc. ca/dspace/bitstream/10625/35237/2/117714.pdf.

de Theije M, Heemskerk M 2009. Moving frontiers in the Amazon: Brazilian small-scale gold miners in Suriname. Eur Rev Latin Am Carib 2009: 5-25.

de Thoisy B, Richard-Hansen C, Goguillon B, Joubert P, Obstancias J, Winterton P, Brosse S 2010. Rapid evaluation of threats to biodiversity: human footprint score and large vertebrate species responses in French Guiana. Biodivers Conserv 19: 1567-1584.

Dedet JP, Germanetto P, Cordoliani G, Bonnevie O, Le Bras J 1988. In vitro activity of various antimalarials (chloroquine, amodiaquine, quinine and mefloquine) against 32 isolates of Plasmodium falciparum in French Guiana. Bull Soc Pathol Exot Filiales 81: 88-93.

Demar M, Carme B 2004. Plasmodium falciparum in vivo resistance to quinine: description of two RIII responses in French Guiana. Am J Trop Med Hyg 70: 125-127.

Dondorp AM, Yeung S, White L, Nguon C, Day NP, Socheat D, von Seidlein L 2010. Artemisinin resistance: current status and scenarios for containment. Nat Rev Microbiol 8: 272-280.

Dusfour I, Carinci R, Issaly J, Gaborit P, Girod R 2013. A survey of adult anophelines in French Guiana: enhanced descriptions of species distribution and biting responses. J Vector Ecol 38: 203-209.

Dusfour I, Issaly J, Carinci R, Gaborit P, Girod R 2012a. Incrimination of Anopheles (Anopheles) intermedius Peryassú, An. (Nyssorhynchus) nuneztovari Gabaldón, An. (Nys.) oswaldoi Peryassú as natural vectors of Plasmodium falciparum in French Guiana. Mem Inst Oswaldo Cruz 107: 429-432.

Dusfour I, Jarjaval F, Gaborit P, Mura M, Girod R, Pages F 2012b. Confirmation of the occurrence of Anopheles (Nyssorhynchus) marajoara in French Guiana. J Am Mosq Control Assoc 28: 309-311.

Ehrman FC, Ellis JM, Young MD 1945. Plasmodium vivax Chesson strain. Science 101: 377.

Esterre P, Cordoliani G, Germanetto P, Robin Y 1990. Epidemiology of malaria in French Guiana. Bull Soc Pathol Exot 83: 193-205.

Esterre P, Volney B, Meynard JB, Legrand E 2009. Intérêt d'un observatoire régional de la chimiorésistance du paludisme, problème émergent de la santé publique dans la région des Guyanes. Bull Soc Pathol Exot 102: 179-184.

Evans L 3rd, Coignez V, Barojas A, Bempong D, Bradby S, Dijiba Y, James M, Bretas G, Adhin M, Ceron N, Hinds-Semple A, Chibwe K, Lukulay P, Pribluda V 2012. Quality of anti-malarials collected in the private and informal sectors in Guyana and Suriname. Malar J 11: 203.

Fandeur T, Volney B, Peneau C, de Thoisy B 2000. Monkeys of the rainforest in French Guiana are natural reservoirs for $P$. brasilianum/P. malariae malaria. Parasitology 120: 11-21.

Fischer J 2012. Malaria: control, elimination and eradication - Historical landmarks. Bull Veille San 1: 2-4.

Floch H 1954. Antimalarial campaign in French Guiana. Bull World Health Organ 11: 579-633.

Floch H 1955. Antimalarial campaign in French Guiana. Riv Malariol 34: 57-76.

Floch H, Abonnenc E 1951. Anopheles in French Guiana. Entomo Guyane 236: 1-92.

Fouque F, Gaborit P, Carinci R, Issaly J, Girod R 2010. Annual variations in the number of malaria cases related to two different patterns of Anopheles darlingi transmission potential in the Maroni area of French Guiana. Malar J 9: 80.

Girod R, Gaborit P, Carinci R, Issaly J, Fouque F 2008. Anopheles darlingi bionomics and transmission of Plasmodium falciparum, Plasmodium vivax and Plasmodium malariae in Amerindian villages of the Ypper-Maroni Amazonian forest, French Guiana. Mem Inst Oswaldo Cruz 103: 702-710.

Girod R, Roux E, Berger F, Stefani A, Gaborit P, Carinci R, Issaly J, Carme B, Dusfour I 2011. Unravelling the relationships between Anopheles darlingi (Diptera: Culicidae) densities, environmental factors and malaria incidence: understanding the variable patterns of malarial transmission in French Guiana (South America). Ann Trop Med Parasitol 105: 107-122.

Hammond DS, Gond V, de Thoisy B, Forget PM, DeDijn BP 2007. Causes and consequences of a tropical forest gold rush in the Guiana Shield, South America. Ambio 36: 661-670.

Hanf M, Stephani A, Basurko C, Nacher M, Carme B 2009. Determination of the Plasmodium vivax relapse pattern in Camopi, French Guiana. Malar J 8: 278.

HCSP - Haut Conseil de la Santé Publique 2008. Elargissement des prescriptions de primaquine dans le cadre du traitement du paludisme à $P$. vivax et $P$. ovale. Available from: hcsp.fr/explore. cgi/hcspa20081017_primaquine.pdf.

Hiwat H, Bretas G 2011. Ecology of Anopheles darlingi Root with respect to vector importance: a review. Parasit Vectors 4: 177.

Hiwat H, Hardjopawiro LS, Takken W, Villegas L 2012. Novel strategies lead to pre-elimination of malaria in previously high-risk areas in Suriname, South America. Malar J 11: 10.

Hiwat H, Issaly J, Gaborit P, Somai A, Samjhawan A, Sardjoe P, Soekhoe T, Girod R 2010. Behavioral heterogeneity of Anopheles darlingi (Diptera: Culicidae) and malaria transmission dynamics along the Maroni River, Suriname, French Guiana. Trans $R$ Soc Trop Med Hyg 104: 207-213.

Hustache S, Nacher M, Djossou F, Carme B 2007. Malaria risk factors in Amerindian children in French Guiana. Am J Trop Med Hyg 76: 619-625.

Insee - Institut National de la Statistique et des Études Économiques 2012. Estimation of the population size, 1st January 2012, according to region, department, sex and age. Available from: insee.fr/ fr/themes/detail.asp?ref_id=estim-pop\&reg_id=99.

InVS - Institut de Veille Sanitaire 2006. Surveillance épidémiologique du paludisme en Guyane. Available from: invs.sante.fr/ publications/2006/paludisme_guyane/paludisme_guyane.pdf.

Jambou R, Legrand E, Niang M, Khim N, Lim P, Volney B, Ekala MT, Bouchier C, Esterre P, Fandeur T, Mercereau-Puijalon O 2005. Resistance of Plasmodium falciparum field isolates to invitro artemether and point mutations of the SERCA-type PfATPase6. Lancet 366: 1960-1963.

James S, Takken W, Collins FH, Gottlieb M 2014. Needs for monitoring mosquito transmission of malaria in a pre-elimination world. Am J Trop Med Hyg 90: 6-10.

Juminer B, Robin Y, Pajot FX, Eutrope R 1981. Features of malaria in Guyana. Bull Soc Pathol Exot Filiales 74: 176-192.

Kublin JG, Cortese JF, Njunju EM, Mukadam RA, Wirima JJ, Kazembe PN, Djimde AA, Kouriba B, Taylor TE, Plowe CV 2003. Reemergence of chloroquine-sensitive Plasmodium falciparum malaria after cessation of chloroquine use in Malawi. J Infect Dis 187: $1870-1875$.

Le Bras J, Deloron P 1983. In vitro study of drug sensitivity of Plasmodium falciparum: evaluation of a new semi-micro test. Am J Trop Med Hyg 32: 447-451.

Legrand E, Demar M, Volney B, Ekala MT, Quinternet M, Bouchier C, Fandeur T, Rogier C, Carme B, Puijalon OM, Esterre P 2007. First case of emergence of atovaquone resistance in Plasmodium falciparum during second-line atovaquone-proguanil treatment in South America. Antimicrob Agents Chemother 51: 2280-2281.

Legrand E, Volney B, Meynard JB, Mercereau-Puijalon O, Esterre P 2008. In vitro monitoring of Plasmodium falciparum drug resist- 
ance in French Guiana: a synopsis of continuous assessment from 1994 to 2005. Antimicrob Agents Chemother 52: 288-298.

Legrand E, Yrinesi J, Ekala MT, Peneau J, Volney B, Berger F, Bouchier C, Bertani S, Musset L, Meynard JB, Mercereau-Puijalon O 2012. Discordant temporal evolution of Pfcrt and Pfmdr1 genotypes and Plasmodium falciparum in vitro drug susceptibility to 4-aminoquinolines after drug policy change in French Guiana. Antimicrob Agents Chemother 56: 1382-1389.

Lepelletier L, Gay F, Nadire-Galliot M, Poman JP, Bellony S, Claustre J, Traore BM, Mouchet J 1989. Malaria in Guiana. I. General status of the endemic. Bull Soc Pathol Exot Filiales 82: 385-392.

Mansotte F, Margueron T, Maison D 2010a. Distribution of drinking water in French Guyana: issues and solutions for improving access. Sante publique 22: 181-192.

Mansotte F, Ravachol F, Carlisi R, Caudal J, Pinchon S, Maison D 2010b. Operation to promote use of long-lasting insecticidal nets (LLIN) in French Guiana in 2006: design, implementation and results. Med Trop (Mars) 70: 249-254.

Mohammed A, Ndaro A, Kalinga A, Manjurano A, Mosha JF, Mosha DF, van Zwetselaar M, Koenderink JB, Mosha FW, Alifrangis M, Reyburn H, Roper C, Kavishe RA 2013. Trends in chloroquine resistance marker, Pfcrt-K76T mutation ten years after chloroquine withdrawal in Tanzania. Malar J 12: 415.

Mouchet J, Nadire-Galliot M, Gay F, Poman JP, Lepelletier L, Claustre J, Bellony S 1989. Malaria in Guiana. II. The characteristics of different foci and antimalarial control. Bull Soc Pathol Exot Filiales 82: 393-405.

Musset L, Bouchaud O, Matheron S, Massias L, Le Bras J 2006. Clinical atovaquone-proguanil resistance of Plasmodium falciparum associated with cytochrome $b$ codon 268 mutations. Microbes Infect 8: 2599-2604.

Musset L, Le Bras J, Clain J 2007. Parallel evolution of adaptive mutations in Plasmodium falciparum mitochondrial DNA during atovaquone-proguanil treatment. Mol Biol Evol 24: 1582-1585.

Nacher M, Guerin PJ, Demar-Pierre M, Djossou F, Nosten F, Carme B 2013a. Made in Europe: will artemisinin resistance emerge in French Guiana? Malar J 12: 152.

Nacher M, Stefani A, Basurko C, Lemonnier D, Djossou F, Demar M, Elenga N, Brousse P, Ville M, Carme B 2013b. The burden of Plasmodium vivax relapses in an Amerindian village in French Guiana. Malar J 12: 367.

Pajot FX, Molez JF, Le Pont F 1978. Anopheles and malaria on the lower Oyapock River, French Guiana. Cah ORSTOM 16: 105-111.

Picot S, Brega S, Gerome P, Velut G, de Monbrison F, Cheminel V, Peyron F 2005. Absence of nucleotide polymorphism in a Plasmodium vivax multidrug resistance gene after failure of mefloquine prophylaxis in French Guyana. Trans R Soc Trop Med Hyg 99: 234-237.

Queyriaux B, Texier G, Ollivier L, Galoisy-Guibal L, Michel R, Meynard JB, Decam C, Verret C, Pommier de Santi V, Spiegel A, Boutin JP, Migliani R, Deparis X 2011. Plasmodium vivax malaria among military personnel, French Guiana, 1998-2008. Emerg Infect Dis 17: 1280-1282.

Reynes J-M, Fargette J, Gaborit P, Yarde S 1997. In vitro responses of Plasmodium falciparum isolates to five antimalaria drugs in French Guiana during 1994 and 1995. Mem Inst Oswaldo Cruz 92: 251-252.

Stefani A, Hanf M, Nacher M, Girod R, Carme B 2011. Environmental, entomological, socioeconomic and behavioural risk factors for malaria attacks in Amerindian children of Camopi, French Guiana. Malar J 10: 246.
Strobel M, Lefait JM, Dedet JP 1985. Plasmodium falciparum malaria in a Wayana Amerindian population from French Guiana. A sero-epidemiological investigation. Med Mal Infect 4: 162-164.

Tadei WP, Thatcher BD, Santos JM, Scarpassa VM, Rodrigues IB, Rafael MS 1998. Ecologic observations on anopheline vectors of malaria in the Brazilian Amazon. Am J Trop Med Hyg 59: 325-335.

Tarantola A, Eltges F, Ardillon V, Lernout T, Sissoko D, Kendjo E, Achirafi A, Thiria J, Flamand C, D’Ortenzio E, Cohuet S, Quatresous I, Quenel P, Filleul L, Gastellu-Etchegorry M 2011. Malaria in France: mainland and territories. Med Mal Infect 41: 301-306.

Trouvay M, Palazon G, Berger F, Volney B, Blanchet D, Faway E, Donato D, Legrand E, Carme B, Musset L 2013. High performance of histidine-rich protein 2 based rapid diagnostic tests in French Guiana are explained by the absence of $p f h r p 2$ gene deletion in $P$. falciparum. PloS ONE 8: e74269.

Veron V, Legrand E, Yrinesi J, Volney B, Simon S, Carme B 2009. Genetic diversity of msp3alpha and msp1_b5 markers of Plasmodium vivax in French Guiana. Malar J 8: 40.

Verret C, Cabianca B, Haus-Cheymol R, Lafille JJ, Loran-Haranqui G, Spiegel A 2006. Malaria outbreak in troops returning from French Guiana. Emerg Infect Dis 12: 1794-1795.

Volney B, Pouliquen JF, De Thoisy B, Fandeur T 2002. A sero-epidemiological study of malaria in human and monkey populations in French Guiana. Acta Trop 82: 11-23.

Vreden SGS, Jitan JK, Bansie RD, Adhin MR 2013. Evidence of an increased incidence of day 3 parasitaemia in Suriname: an indicator of the emerging resistance of Plasmodium falciparum to artemether. Mem Inst Oswaldo Cruz 108: 968-973.

Wang X, Mu J, Li G, Chen P, Guo X, Fu L, Chen L, Su X, Wellems TE 2005. Decreased prevalence of the Plasmodium falciparum chloroquine resistance transporter $76 \mathrm{~T}$ marker associated with cessation of chloroquine use against $P$. falciparum malaria in Hainan, People's Republic of China. Am J Trop Med Hyg 72: 410-414.

WHO - World Health Organization 2009a. Methods for surveillance of antimalarial drug efficacy. Available from: whqlibdoc.who.int/ publications/2009/9789241597531_eng.pdf.

WHO - World Health Organization 2009b. Technical consultation on combining indoor residual spraying and long lasting insecticidal net interventions. Meeting Report, Global Malaria Programme, 4-6 February 2009, WHO Headquarters, Geneve, 55 pp.

WHO - World Health Organization 2010. The technical basis for coordinated action against insecticide resistance: preserving the effectiveness of modern malaria vector control. Meeting Report, Global Malaria Programme, 4-6 May 2010, WHO Headquarters, Geneve, 36 pp.

WHO - World Health Organization 2011. Global report on antimalarial drug efficacy and drug resistance: 2000-2010. Available from: whqlibdoc.who.int/publications/2010/9789241500470_eng.pdf.

WHO - World Health Organization 2013. World malaria report 2013. Available from: who.int/malaria/publications/world_malaria report_2013/en/.

Witkowski B, Amaratunga C, Khim N, Sreng S, Chim P, Kim S, Lim P, Mao S, Sopha C, Sam B, Anderson JM, Duong S, Chuor CM, Taylor WR, Suon S, Mercereau-Puijalon O, Fairhurst RM, Menard D 2013. Novel phenotypic assays for the detection of artemisinin-resistant Plasmodium falciparum malaria in Cambodia: in-vitro and ex-vivo drug-response studies. Lancet Infect Dis 13: 1043-1049.

WWF - World Wildlife Fund 2010. From the mine to the showcase. Available from: guyane.wwf.fr/wp-content/uploads/2009/11/ Rapport-De-la-mine-\%C3\%A0-la-vitrine-WWF.pdf. 